\title{
Titanocene dichloride: A new green reagent in organic chemistry
}

\author{
Antonio Rosales Martínez *, María Castro Rodríguez, Ignacio Rodríguez-García, \\ Laura Pozo Morales, Roman Nicolay Rodríguez Maecker
}

Green reagents reduce or eliminate the use and generation of hazardous substances in the synthesis of chemical compounds [1]. The development of new green reagents is important for the development of a more sustainable chemical industry, based on processes that follow the principles dictated by green chemistry [2]. In this context, the use of green reagents, such as hydrogen peroxide and dimethyl carbonate, in reactions that can be driven by sunlight, have been widely developed over the past twenty years. Alternative methodologies have been implemented in chemical synthesis to catalyze reactions under safe and mild reaction conditions with the use of less harmful solvents and with reduced toxic waste production. Polymer supported reagents [3] have enabled many elegant and efficient strategies for performing a range of different transformations. The main advantage of polymer supported reagents is that excess reagent can be recovered by filtration and reused. However, many previously developed green reagents are applicable only to a very limited number of chemical transformations and substoichiometric amounts must be used.

In this paper, we highlight the effectiveness of $\mathrm{Cp}_{2} \mathrm{TiCl}$ as a reagent that fulfils many of the principles of green chemistry, including high catalytic activity, low toxicity, high selectivity, and compatibility with environmentally benign solvents [4].

$\mathrm{Cp}_{2} \mathrm{TiCl}$, is a single electron transfer system (SET) obtained from non-hazardous materials such as $\mathrm{Cp}_{2} \mathrm{TiCl}_{2}$ and $\mathrm{Mn}$ or $\mathrm{Zn}$ [5]. Alternatively, organosilicon reducing agents can be used, thus avoiding reductant-derived metal waste [6]. Although, it is not a renewable feedstock, $\mathrm{Cp}_{2} \mathrm{TiCl}$, is derived from titanium, one of the most widely abundant and safe transition metals in the Earth's crust [7]. This reagent has been shown to be capable of promoting and/or catalyzing [8] homolytic cleavage of C-O, $\mathrm{C}$-halogen, and $\mathrm{O}-\mathrm{O}$ bonds, present in functional groups such as epoxides, ozonides, oxetanes, imines, halides, and carbonyl groups. A breakthrough in the application of this reagent was described by Gansäuer et al. [9] and Oltra et al. [10], with the development of two catalytic cycles, which allowed regeneration of $\mathrm{Cp}_{2} \mathrm{TiCl}_{2}$ from the titanium derivatives formed in homolytic cleavage of bonds (Figs. 1 and 2). The amount of $\mathrm{Cp}_{2} \mathrm{TiCl}$ used in these catalytic cycles ranges between ( 5 and 20 ) $\mathrm{mol} \%$.
Both catalytic cycles for epoxide ring opening are shown in Figs. 1 and 2.

In this context, both catalytic procedures minimize waste generation, contributing to the development of sustainable chemical processes. Although $\mathrm{Mn}$ or $\mathrm{Zn}$ is used as stoichiometric reagents (2-8 eq) both can be recovered by simple filtration. Furthermore, an economically attractive feature is that the collidine used in both catalytic cycles can be easily recovered during the reaction work-up by simple acid-base extraction [5]. Reactions catalyzed by this SET are conducted at atmospheric pressure and room temperature, which contributes

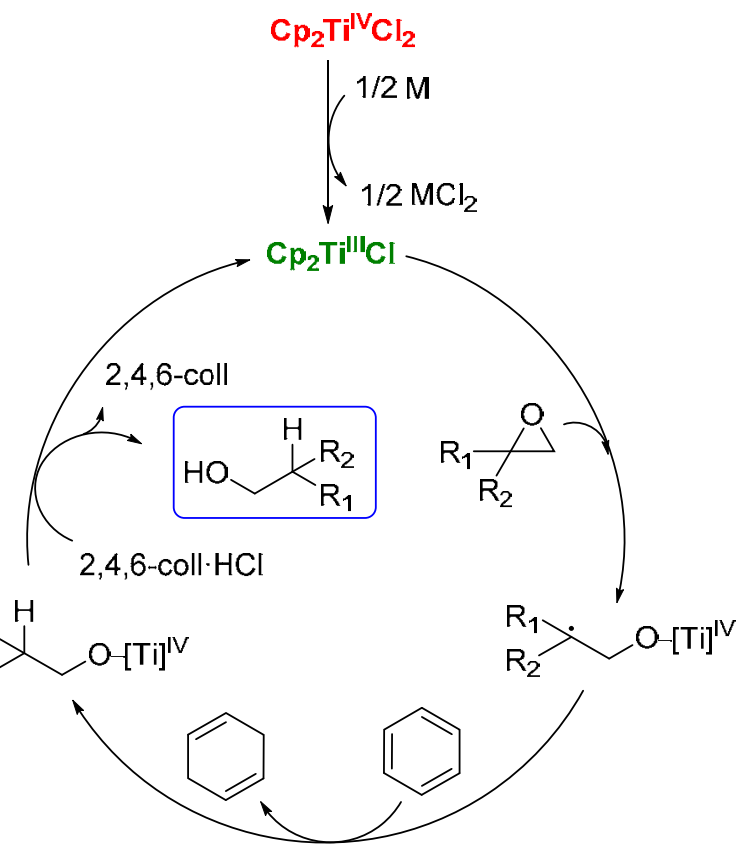

$$
\begin{array}{ll}
M=M n, Z n \quad & \mathrm{R}_{1}=\mathrm{CH}_{3}, \mathrm{R}_{2}=\mathrm{CH}_{2} \mathrm{CH}_{2} \mathrm{Ph} \\
& \text { Yield }=88 \%
\end{array}
$$

Fig. 1. Ti-catalyzed reductive epoxide ring-opening reactions. 


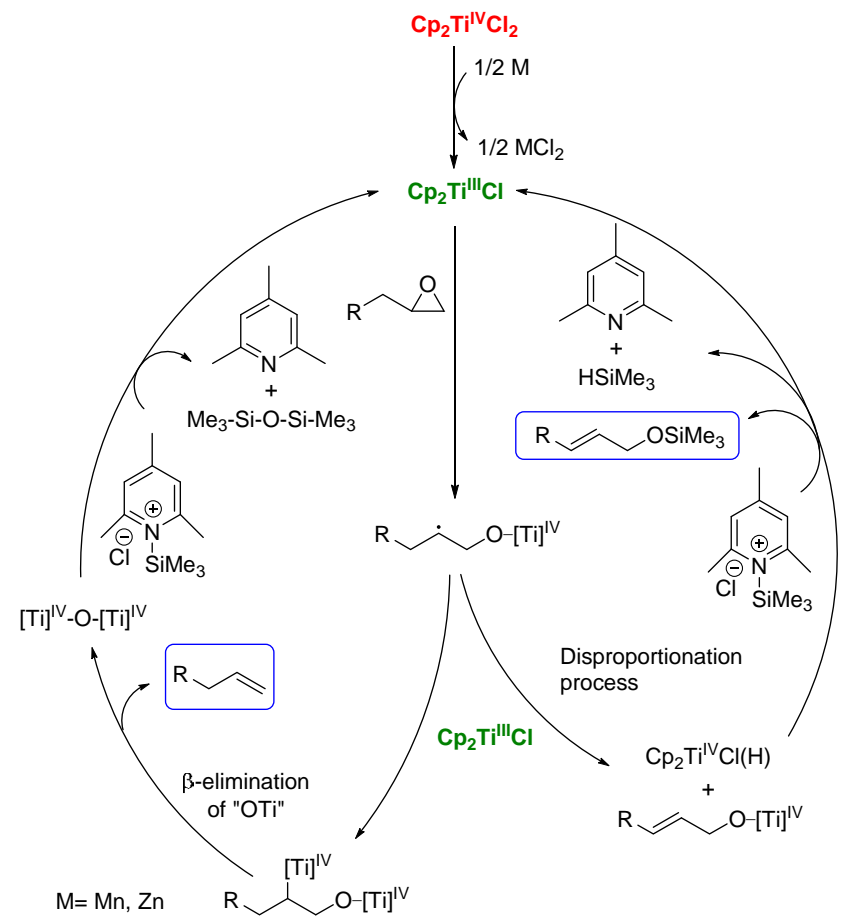

Fig. 2. Ti-catalyzed non-reductive epoxide ring-opening reactions.

to high energy efficiency. The reactions are also compatible with functional groups including ethers, silanes, and esters. Another aspect to consider in green chemistry is the use of solvents with low risk to human health and low toxicity [11]. In this respect $\mathrm{Cp}_{2} \mathrm{TiCl}$ is environmentally friendly, because toluene or tetrahydrofuran $[12,13]$ can be used to generate $\mathrm{Cp}_{2} \mathrm{TiCl}$ from $\mathrm{Cp}_{2} \mathrm{TiCl}_{2}$ and $\mathrm{Mn}$; these solvents are classified as usable by

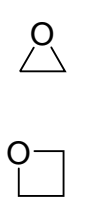<smiles>[R]CC1OCOO1</smiles><smiles>[X]CC=C</smiles><smiles>C=N</smiles><smiles>[X]CCCC</smiles><smiles>[X]CC#C</smiles><smiles>[R]C([R2])=O</smiles>

$$
\begin{aligned}
& \mathrm{X}: \mathrm{Cl}, \mathrm{Br} \\
& \mathrm{R}: \mathrm{H} \text {, alkyl, phenyl... }
\end{aligned}
$$

Fig. 3. Target functional groups of $\mathrm{Cp}_{2} \mathrm{TiCl}$.

Pfizer scientists in their practical guide for solvents for medicinal chemists [14]. Finally, $\mathrm{Cp}_{2} \mathrm{TiCl}$ is a reagent that has contributed to the development of selective processes with high-step economy [15]. Especially relevant is the cyclization of epoxipolyprenes, catalyzed by $\mathrm{Cp}_{2} \mathrm{TiCl}$, to obtain polycyclic $\mathrm{C}_{10}, \mathrm{C}_{15}$, $\mathrm{C}_{20}$ and $\mathrm{C}_{30}$ terpenoids [8]. This reaction mimics their biosynthesis but proceeds through a free radical pathway. This reactivity reinforces the effectiveness of $\mathrm{Cp}_{2} \mathrm{TiCl}$ as a green reagent, which complies with the principles of green chemistry as reported by Anastas et al. [2].

The main applications of this new green catalyst are summarized below. A useful feature of $\mathrm{Cp}_{2} \mathrm{TiCl}$ is its ability to form carbon-centered radicals by homolytic cleavage of $\mathrm{C}-\mathrm{X}$ bonds present in several functional groups [8] (Fig. 3).

Reduction reactions of these carbon-centered radicals usually take place in the presence of water, which is a good hydrogen-atom donor. An $\mathrm{H}$ atom is transferred from $\mathrm{H}_{2} \mathrm{O}$ to the carbon radical $[12,16-18]$ or to the titanaoxirane intermediate [19] (Fig. 4). This reduction has been postulated to be greener than traditional processes for reducing carbonyl groups and

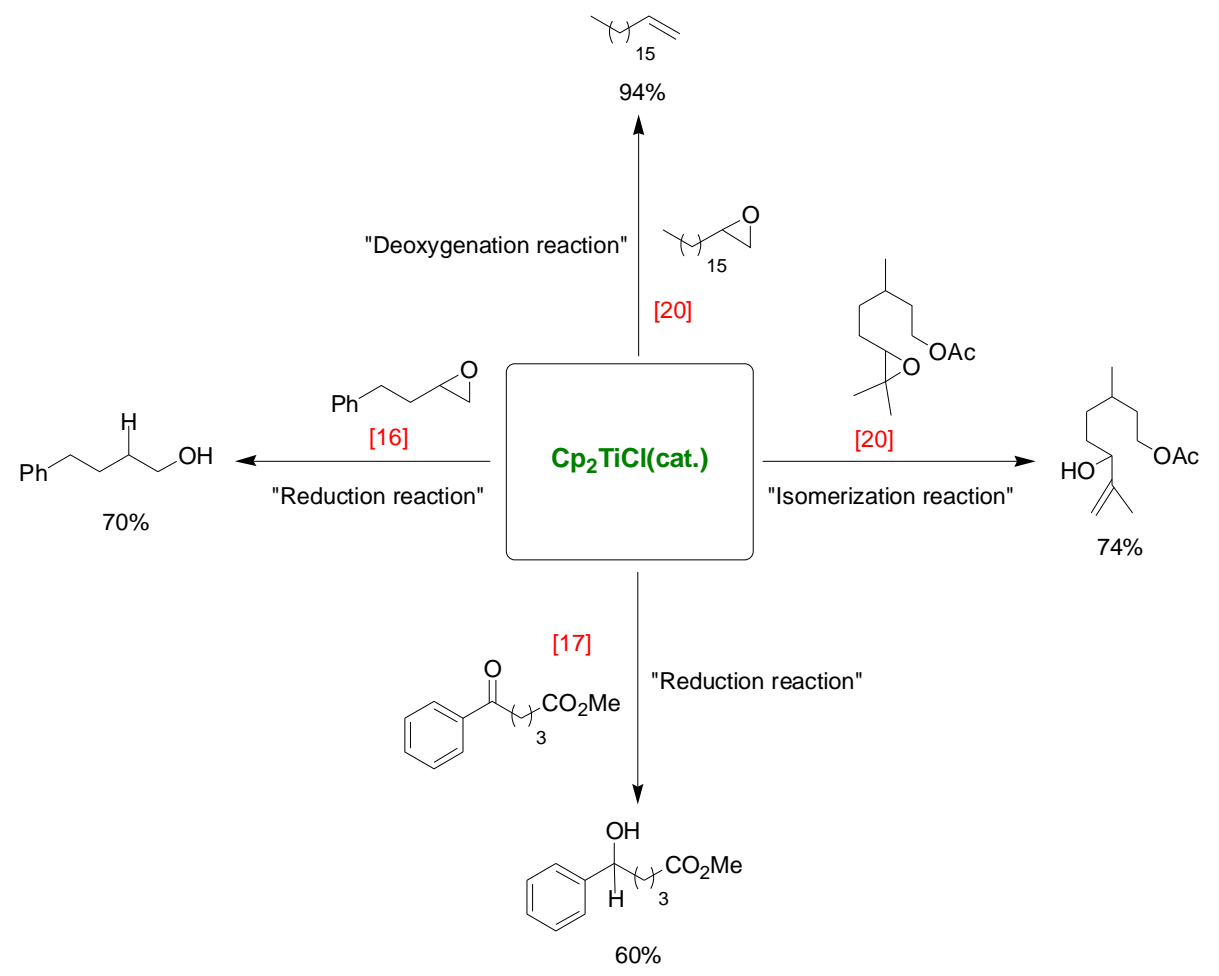

Fig. 4. $\mathrm{Cp}_{2} \mathrm{TiCl}$-catalyzed reduction, deoxygenation, and isomerization reactions. 


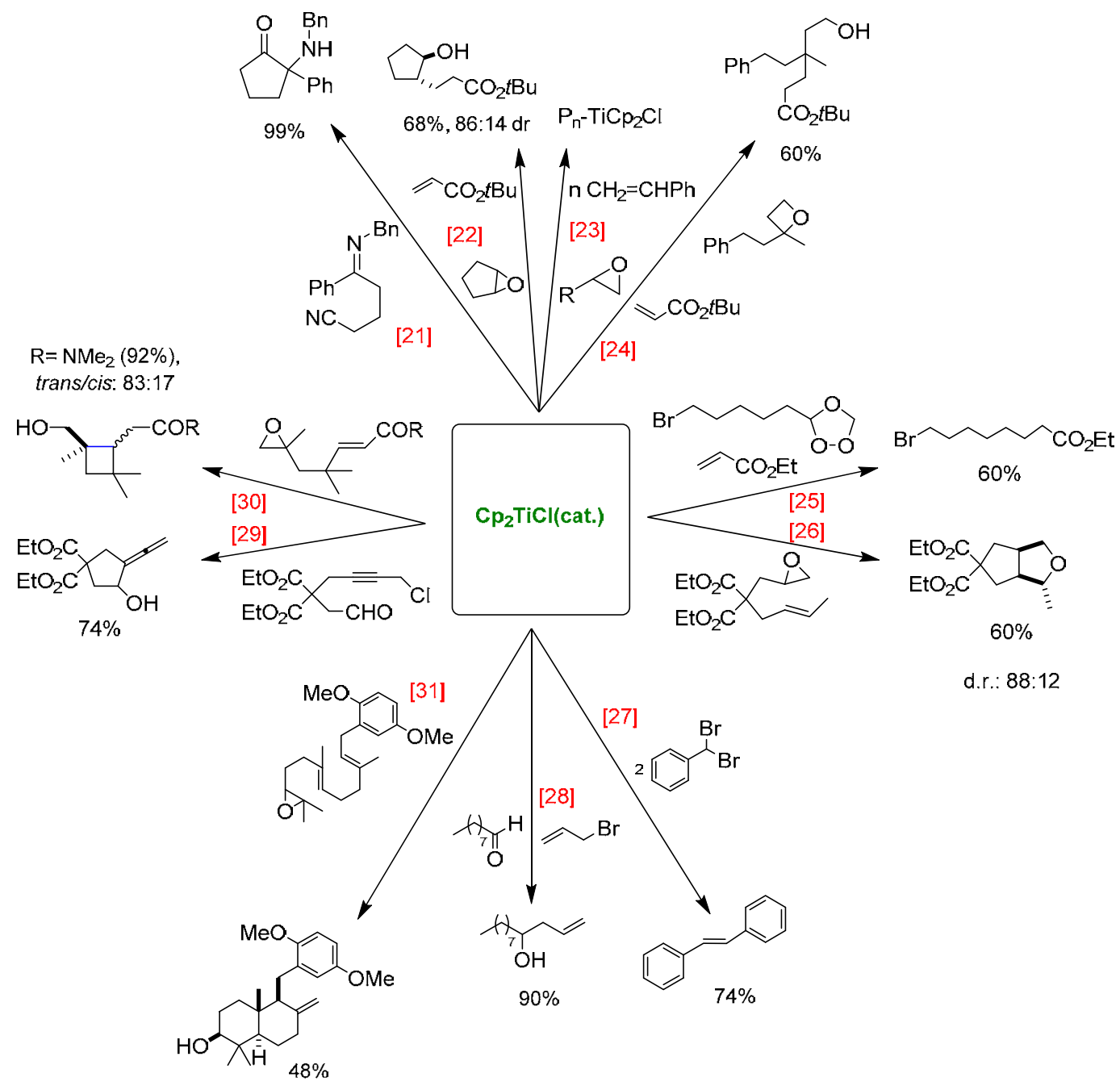

Fig. 5. $\mathrm{Cp}_{2}$ TiCl-catalyzed $\mathrm{C}-\mathrm{C}$ and $\mathrm{C}-\mathrm{O}$ bond forming reactions.

alkenes. In the absence of good hydrogen-atom donors or electron-withdrawing functional groups, epoxides react to yield alkenes or allylic alcohols through a mixed disproportionation process [20]. In this way, tertiary carbon radicals lead to allylic alcohols through a process in which $\mathrm{Cp}_{2} \mathrm{TiCl}$ removes a $\alpha$ radical hydrogen atom (isomerization process, Fig. 4) [20]. If the radical is on a di-substituted carbon, a double bond is formed (deoxygenation process, Fig. 4). In this case, the radical is trapped by a second $\mathrm{Cp}_{2} \mathrm{TiCl}$ species to form a bimetallic intermediate, which eventually leads to the formation of a double bond.

However, when these carbon-centered radicals form in the absence of a hydrogen-atom donor and in the presence of electron withdrawing groups, a new $\mathrm{C}-\mathrm{C}$ or $\mathrm{C}-\mathrm{O}$ bond can be generated, either through intra- or intermolecular $\mathrm{C}-\mathrm{C}$ and $\mathrm{C}-\mathrm{O}$ bond forming reactions (Fig. 5) [8]. The $\mathrm{C}-\mathrm{C}$ bond forming reactions reported in Fig. 5 [21-30] show that $\mathrm{Cp}_{2} \mathrm{TiCl}$ is a reagent widely used for this type of reactions and applied to different functional groups, where high diastereoselectivity and high yields can be achieved. The synthesis of natural terpenes from cyclization of monoepoxides of acyclic polyprenes [31] is currently achieved through the use of $\mathrm{Cp}_{2} \mathrm{TiCl}$ in $\mathrm{C}-\mathrm{C}$ bond forming reactions.

Beyond mechanistic considerations, depending on the reaction conditions, $\mathrm{Cp}_{2} \mathrm{TiCl}$ has emerged as an excellent green reagent for $\mathrm{C}-\mathrm{C}$ and $\mathrm{C}-\mathrm{O}$ bond forming reactions, reduction, deoxygenation, and isomerization reactions. Several examples of this catalytic processes are presented in Figs. 4 and 5.

In summary, $\mathrm{Cp}_{2} \mathrm{TiCl}$ is an useful reagent for many different green transformations in chemistry, offering high selectivity, cost effectiveness, high efficiency, and environmental compatibility. This reagent will contribute to developments in green chemistry owing to its wide range of applications in the synthesis of natural products, polymers, and fine chemicals. In this context, $\mathrm{Cp}_{2} \mathrm{TiCl}$ might enable new catalytic methodologies that will be useful for environmentally compatible industrial chemical processes.

Antonio Rosales Martínez (Corresponding author) Department of Chemical Engineering, Escuela Politécnica Superior, University of Sevilla, 41011 Sevilla, Spain Petrochemical Engineering, Universidad de las Fuerzas Armadas-ESPE, 050150 Latacunga, Ecuador E-mail: arosales@us.es 
Laura Pozo Morales and María Castro Rodríguez

Department of Chemical Engineering, Escuela Politécnica

Superior, University of Sevilla, 41011 Sevilla, Spain

Ignacio Rodríguez-García

Organic Chemistry, ceiA3, University of Almería, 04120 Almería, Spain

Roman Nicolay Rodríguez Maecker

Petrochemical Engineering, Universidad de las Fuerzas

Armadas-ESPE, 050150 Latacunga, Ecuador

Received 22 June 2017

Published 5 October 2017

DOI: $10.1016 /$ S1872-2067(17)62894-8

\section{References}

[1] P. Tundo, V. Esposito, Green Chemical Reactions, Springer, The Netherlands, 2006.

[2] P. T. Anastas, J. C. Warner, Green Chemistry: Theory and Practice, Oxford University Press, Oxford, 2000.

[3] M. Bradley, N. Galaffu, Polymer-Supported Reagents Encyclopedia of Polymer Science, Wiley, 2004.

[4] M. Castro Rodríguez, I. Rodríguez García, R. N. Rodríguez Maecker, L. Pozo Morales, J. E. Oltra, A. Rosales Martínez, Org. Process Res. Dev., 2017, 21, 911-923.

[5] A. Gansäuer, H. Bluhm, M. Pierobon, J. Am. Chem. Soc., 1998, 120, 12849-12859.

[6] T. Saito, H. Nishiyama, H. Tanahashi, K. Kawakita, H. Tsurugi, K. Mashima, J. Am. Chem. Soc., 2014, 136, 5161-5170.

[7] D. J. Ramón, M. Yus, Chem. Rev., 2006, 106, 2126-2208.

[8] A. Rosales, I. Rodríguez-García, J. Muñoz-Bascón, E. Roldán-Molina, N. M. Padial, L. P. Morales, M. García-Ocaña, J. E. Oltra, Eur. J. Org. Chem., 2015, 2015, 4567-4591.

[9] A. Gansäuer, M. Pierobon, H. Bluhm, Angew. Chem. Int. Ed., 1998, 37, 101-103.

[10] A. F. Barrero, A. Rosales, J. M. Cuerva, J. E. Oltra, Org. Lett., 2003, 5, 1935-1938.

[11] R. A. Sheldon, Chem. Soc. Rev., 2012, 41, 1437-1451.

[12] A. F. Barrero, J. E. Oltra, J. M. Cuerva, A. Rosales, J. Org. Chem.,
2002, 67, 2566-2571.

[13] P. Bichovski, T. M. Haas, M. Keller, J. Streuff, Org. Biomol. Chem., 2016, 14, 5673-5682.

[14] Guidelines for solvents used in the pharmaceutical industry. http://www.fda.gov/cder/guidance/index.htm (accessed March 12, 2017).

[15] B. M. Trost, Science, 1991, 254, 1471-1477.

[16] J. M. Cuerva, A. G. Campaña, J. Justicia, A. Rosales, J. L. Oller-López, R. Robles, D. J. Cárdenas, E. Buñuel, J. E. Oltra, Angew. Chem. Int. $E d ., 2006,45,5522-5526$.

[17] A. F. Barrero, A. Rosales, J. M. Cuerva, A. Gansäuer, J. E. Oltra, Tetrahedron Lett., 2003, 44, 1079-1082.

[18] A. Gansäuer, M. Behlendorf, A. Cangönül, C. Kube, J. M. Cuerva, J. Friedrich, M. van Gastel, Angew. Chem. Int. Ed., 2012, 51, 3266-3270.

[19] A. Rosales, J. Muñoz-Bascón, E. Roldán-Molina, M. A. Castañeda, N. M. Padial, A. Gausäuer, I. Rodríguez-García, J. E. Oltra, J. Org. Chem., 2014, 79, 7672-7676.

[20] J. Justicia, T. Jiménez, S. P. Morcillo, J. M. Cuerva, J. E. Oltra, Tetrahedron, 2009, 65, 10837-10841.

[21] M. Feurer, G. Frey, H. T. Luu, D. Kratzert, J. Streuff, Chem. Commun., 2014, 50, 5370-5372.

[22] J. Streuff, A. Gansäuer, Angew. Chem. Int. Ed., 2015, 54, 14232-14242.

[23] A. D. Asandei, I. W. Moran, J. Am. Chem. Soc., 2004, 126, 15932-15933.

[24] A. Gansäuer, N. Ndene, T. Lauterbach, J. Justicia, I. Winkler, C. Mück-Lichtenfeld, S. Grimme, Tetrahedron, 2008, 64, 11839-11845.

[25] A. Rosales, J. Muñoz-Bascón, C. López-Sánchez, M. Álvarez-Corral, M. Muñoz-Dorado, I. Rodríguez-García, J. E. Oltra, J. Org. Chem., 2012, 77, 4171-4176.

[26] A. Gansäuer, B. Rinker, M. Pierobon, S. Grimme, M. Gerenkamp, C. Mück-Lichtenfeld, Angew. Chem. Int. Ed., 2003, 42, 3687-3690.

[27] A. F. Barrero, M. M. Herrador, J. F. Q. del Moral, P. Arteaga, M. Akssira, F. El Hanbali, J. F. Arteaga, H. R. Diéguez, E. M. Sánchez, J. Org. Chem., 2007, 72, 2251-2254.

[28] A. Rosales, J. L. Oller-López, J. Justicia, A. Gansäuer, J. E. Oltra, J. M. Cuerva, Chem. Commun., 2004, 2628-2629.

[29] J. Muñoz-Bascón, C. Hernández-Cervantes, N. M. Padial, M. Álvarez-Corral, A. Rosales, I. Rodríguez-García, J. E. Oltra, Chem. Eur. J., 2014, 20, 801-810.

\section{Graphical Abstract}

Chin. J. Catal., 2017, 38: 1659-1663 doi: 10.1016/S1872-2067(17)62894-8

\section{Titanocene dichloride: A new green reagent in organic chemistry}

Antonio Rosales Martínez *, María Castro Rodríguez, Ignacio

Rodríguez-García, Laura Pozo Morales, Roman Nicolay Rodríguez Maecker

University of Sevilla, Spain; University of Almería, Spain;

Universidad de las Fuerzas Armadas-ESPE, Ecuador

This review presents $\mathrm{Cp}_{2} \mathrm{TiCl}$ as a new green reagent widely used in organic chemistry, with potential applications in fine chemistry, polymer chemistry and other fields.

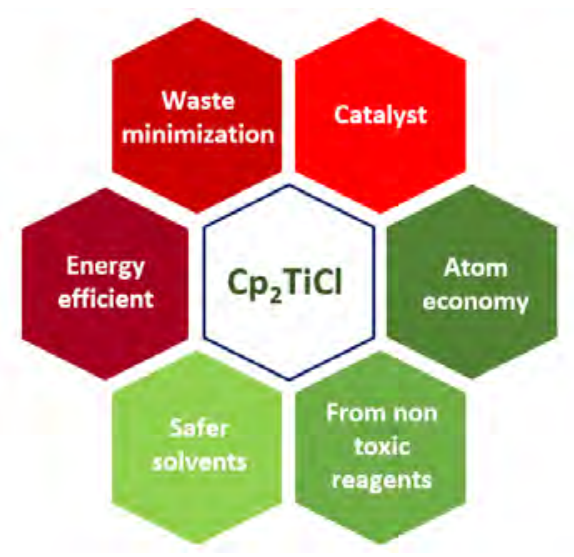


[30] J. Friedrich, K. Walczak, M. Dolg, F. Piestert, T. Lauterbach, D. Worgull, A. Gansäuer, J. Am. Chem. Soc., 2008, 130, 1788-1796.
[31] A. Rosales, J. Muñoz-Bascón, E. Roldán-Modina, N. Rivas-Bascón, N. M. Padial, R. Rodríguez-Maecker, I. Rodríguez-García, J. E. Oltra, J. Org. Chem., 2015, 80, 1866-1870.

\section{$\mathbf{C p}_{2}$ TiCl: 有机化学中广泛使用的新绿色试剂}

Antonio Rosales Martínez ${ }^{\text {ac,** }}$, María Castro Rodríguez a , Ignacio Rodríguez-García b , Laura Pozo Morales ${ }^{\text {a }}$, Roman Nicolay Rodríguez Maecker ${ }^{c}$

a 塞维利亚大学化学工程系, 塞维利亚41011, 西班牙

b阿尔默大学有机化学系, 阿尔莫04120, 西班牙

c 富埃尔萨斯舰队大学石油工程系, 拉塔昆加050150, 厄瓜多尔

摘要: $\mathrm{Cp}_{2} \mathrm{TiCl}$ 是一个单电子转移试剂, 广泛用于有机化学中. 它具有高选择性、廉价、高效且环境友好的特点. 该试剂至 少满足绿色化学12准则中的大多数条件, 如涉及催化过程、毒性小、溶剂安全、产生的废料少、原子经济和能源效率高等 优点.

关键词: 绿色化学; 均相催化; 环境催化; 茂基钛(III); 自由基化学

收稿日期: 2017-06-22. 接受日期: 2017-08-02. 出版日期: 2017-10-05.

*通讯联系人. 电子信箱: arosales@us.es

本文的英文电子版由Elsevier出版社在ScienceDirect上出版(http://www.sciencedirect.com/science/journal/18722067). 